\title{
KETERKAITAN DISPARITAS WILAYAH DENGAN INTERAKSI SPASIAL DI KOTA BEKASI
}

\author{
Dessy Angga Afrianti*, Sabrina Handayani \\ Politeknik Transportasi Darat Indonesia-STTD, Jl. Raya Setu No.89, Kabupaten Bekasi, Provinsi Jawa Barat, \\ Indonesia 17520 \\ *dessy.angga@ptdisttd.ac.id
}

\begin{abstract}
ABSTRAK
Fenomena sistem transportasi dapat memicu terjadinya proses dan perkembangan spasial yang lebih kompleks dimana akan berimplikasi pada perubahan konfigurasi secara spasial dalam konteks sosial ekonomi, tata guna dan pemanfaatan lahan, utilitas dan transportasi. Metode penelitian yang akan digunakan pada penelitian ini yaitu penalaran deduktif kualitatif untuk menganalisis hubungan interaksi antarmoda transportasi darat dengan penggunaan ruang. Teknik pengumpulan data dibagi menjadi dua yaitu observasi (melakukan pengamatan dengan mempertimbangkan secara langsung terhadap objek penelitian untuk memperkuat fakta atau temuan yang diperoleh dari berbagai sumber) dan dokumentasi terhadap dokumen-dokumen yang berhubungan dengan objek studi. Teknik analisis yang digunakan yaitu metode klasifikasi supervised. Pola perkembangan kawasan terbangun Kota Bekasi berdasarkan analisis yang menunjukkan bahwa setiap kecamatan di Kota Bekasi mengalami pertambahan luasan kawasan terbangun yang cukup siginifikan. Jumlah persentase kawasan terbangun dari 2010-2019 meningkat sebesar 1,02\%. Peningkatan persentase kawasan terbangun dipengaruhi juga oleh laju pertumbuhan penduduk yang menyebabkan meningkatnya kepadatan penduduk. misalnya yaitu kepadatan penduduk Kecamatan Medan Satria Tahun 2010 yaitu 9.528 jiwa $/ \mathrm{km}^{2}$ menjadi 13.272 jiwa/ $\mathrm{km}^{2}$ pada Tahun 2019. Berdasarkan hasil analisis distribusi perjalanan bahwasanya terdapat ketimpangan spasial terkait perkembangan fungsi guna lahan yaitu pada Kecamatan Bekasi Utara dan Kecamatan Bantar Gebang. Dimana Kecamatan Bekasi Utara memiliki tingkat bangkitan dan tarikan tertinggi baik dari tahun 2010 dan 2019, sedangkan Kecamatan Bantar Gebang memiliki bangkitan dan tarikan terendah. Perubahan fungsi land use di sebagian besar daerah dapat mempengaruhi kegiatan transportasi sehingga menyebabkan peningkatan jumlah perjalanan dari satu daerah ke daerah lain. Faktor utama penyebab perkembangan pesat Kota Bekasi yaitu karena berbatasan langsung dengan kota megapolitan DKI Jakarta dan Kabupaten Bekasi yang menjadi rencana pusat kegiatan nasional berupa kawasan industri.
\end{abstract}

Kata kunci: aksesibilitas; land use; spasial

\section{REGIONAL DISPARITY RELATIONSHIP WITH SPATIAL INTERACTIONS IN BEKASI CITY}

\begin{abstract}
The phenomenon of the transportation system can trigger more complex spatial processes and developmentswhich will have implications for changes in spatial configuration in the context of socioeconomic, land use and use, utility and transportation. The research method used in this research is qualitative deductive reasoning to analyze the relationship between land transportation and space use. Data collection techniques are divided into two, namely observation (making observations by directly considering the object of research to strengthen facts or findings obtained from various sources) and documentation of documents related to the object of study. The analysis technique used is the supervised classification method.The development pattern of the Bekasi City built area is based on an analysis showing that each sub-district in Bekasi City has a significant increase in the area of the builtup area. The percentage of built-in areas from 2010-2019 increased by 1,02\%. The increase in the percentage of built-up areas is also influenced by the rate of population growth which causes an increase in population density. For example, the population density ofMedan Satria Subdistrict in 2010 was 9,528 people / $\mathrm{km}^{2}$ to 13,272 people / $\mathrm{km}^{2}$ in 2019. Based on the results of the trip distribution analysis, there are spatial imbalances related to the development of land use functions, namely in North Bekasi District and Bantar Gebang District. Where North Bekasi District had the highest
\end{abstract}


generation and attraction rates both from 2010 and 2019, while Bantar Gebang District had the lowest generation and attraction. Changes in land use function in most areas can affect transportation activities, causing an increase in the number of trips from one area to another. The main factor causing the rapid development of Bekasi City is that it is directly adjacent to the megapolitan city of DKI Jakarta and Bekasi Regency which are the plans forthe center of national activities in the form of industrial estates.

Keywords: accessibility; land use; spatial

\section{PENDAHULUAN}

Interaksi antar wilayah tercermin pada keadaan fasilitas transportasi serta aliran orang, barang, maupun jasa. Transportasi menjadi tolak ukur dalam interaksi keruangan antar wilayah dan sangat penting peranannya dalam menunjang proses perkembangan suatu wilayah. Wilayah dengan kondisi geografis yang beragam memerlukan keterpaduan antar jenis transportasi dalam melayani kebutuhan masyarakat Hurst (1974), dikutip oleh Armin Atmajaya (2011). Pada dasarnya sistem transportasi dikembangkan untuk menghubungkan dua lokasi guna lahan yang mungkin berbeda serta untuk memindahkan orang atau barang dari satu tempat ke tempat lain sehingga mempunyai nilai ekonomi yang meningkat. Di negara berkembang, fenomena tersebut memicu terjadinya proses dan perkembangan spasial yanglebih kompleks. Perkembangan ini berimplikasi pada perubahan konfigurasi secara spasial dalam konteks sosial ekonomi, tata guna dan pemanfaatan lahan, utilitas dan transportasi.

Perkembangan spasial kawasan perkotaan berdampak pada perubahan fungsi lahan. Dalam hal tersebut, salah satu dampak terbesar dari perubahan penggunaan lahan adalah transportasi. Secara kualitatif perubahan penggunaan lahan dapat diprediksi dengan memasukkan faktor faktor fisik, sosial, ekonomi, dan kebijakan (Munibah $d k k$, 2010). Kota Bekasi merupakan bagian dari wilayah Provinsi Jawa Barat yang berbatasan langsung dengan Provinsi DKI Jakarta. Kota Bekasi mulai terbentuk pada tahun 1997. Pada awalnya pada tahun 2001 sampai 2004 Kota Bekasi terbagi dalam 10 Kecamatan dan 52 Kelurahan, namun pada tahun 2005 sesuai dengan Peraturan Daerah Kota Bekasi Nomor 04 Tahun 2004 tentang Pemekaran Wilayah Administrasi Kecamatan dan Kelurahan maka Kota Bekasi terbagi menjadi 12 Kecamatan dan 56 Kelurahan dengan luas secara keseluruhan sekitar 21.049.000 Km2. Kecamatan dengan wilayah terluas adalah Kecamatan Mustika Jaya yaitu sekitar $11,75 \%$ dari keseluruhan Kota Bekasi. Sedangkan Kecamatan dengan luas wilayah terendah adalah Kecamatan Bekasi Timur yaitu 1.349 Ha (1.349.000 km2 ) atau sekitar 6,41\% dari luas keseluruhan Kota Bekasi.

Berdasarkan data dari Dinas Tata Ruang dan Permukiman Kota Bekasi tahun 2010, potensi besar dijumpai kawasan kumuh terdapat dibeberapa wilayah kecamatan seperti; Kecamatan Bekasi Utara,Bekasi Timur, Bekasi Selatan, Medan Satria dan Bantargebang. Hal ini terdapat kesamaan dengan prediksi yang tertuang dalam dokumen RDTR Kota Bekasi untuk tahun 2006-2007, bahwa Kecamatan Bekasi Selatan merupakan salah satu kecamatan yang berpotensi besar meningkatnya pertumbuhan kawasan kumuh karena merupakan pusat pengembangan permukiman, pusat perdagangan dan jasa, industri serta sebagai pusat pelayanan sosial. Dalam konteks perkembangan kawasan kumuh di Kota Bekasi, dijumpai beberapa lokasi yang dominan tumbuh bangunan kumuhyaitu di Kelurahan Margajaya (10,05 Ha), dan Kelurahan Pekayon Jaya (6,8 Ha) di Kecamatan Bekasi Selatan, dan Kelurahan Jaka Setia (6 Ha) di Kecamatan Bekasi Selatan (Distarkim Kota Bekasi, 2006). Beberapa identifikasi permasalahan pada kegiatan permukiman di Kota Bekasi dewasa ini adalah ketidakseimbangan supply-demand, terbatas lahan untuk permukiman, masih banyaknya kawasan/bangunan kumuh, serta sarana dan prasarana yang masih banyak belum memadai. 


\section{METODE}

Metode pendekatan yang dilakukan pada penelitian ini adalah dengan menggunakan pendekatan kualitatif eksploratif dengan pengamatan empirik melalui observasi dan pengukuran untuk menganalisis interaksi antarmoda transportasi darat dan implikasinya secara spasial. Penelitian ini menggunakan pendekatan rasionalistik yang berdasarkan kerangka teoritik yang dibangun dari pemaknaan hasil penelitian serupa yang terdahulu dan dikonstruksikan menjadi sesuatu yang problematik untuk diteliti. Dalam penerapannya, pendekatan tersebut merumuskan konsep berdasarkan teori-teori spasial untuk menemukan variabel yang relevan, lalu dilakukan generalisasi hasil penelitian yang akan membawa pada sebuat kesimpulan.

Metode penelitian yang akan digunakan pada penelitian ini yaitu penalaran deduktif kualitatif untuk menganalisis hubungan interaksi antarmoda transportasi darat dengan penggunaan ruang. Teknik pengumpulan data dibagi menjadi dua yaitu observasi (melakukan pengamatan dengan mempertimbangkan secara langsung terhadap objek penelitian untuk memperkuat fakta atau temuan yang diperoleh dari berbagai sumber) dan dokumentasi terhadap dokumendokumen yang berhubungan dengan objek studi. Penentuan sampel dalam penelitian ini yaitu dengan teknik Purposive Sampling (mengambil subjek bukan didasarkan atas strata, random atau daerah tetapi didasarkan atas adanya tujuan tertentu) dan Snowball Sampling (dengan mengambil sampel sumber data yang pada awalnya sedikit). Teknik analisis data pada penelitian ini yaitu memadukan antara analisis kualitatif dan kuantitatif.

\section{HASIL DAN PEMBAHASAN}

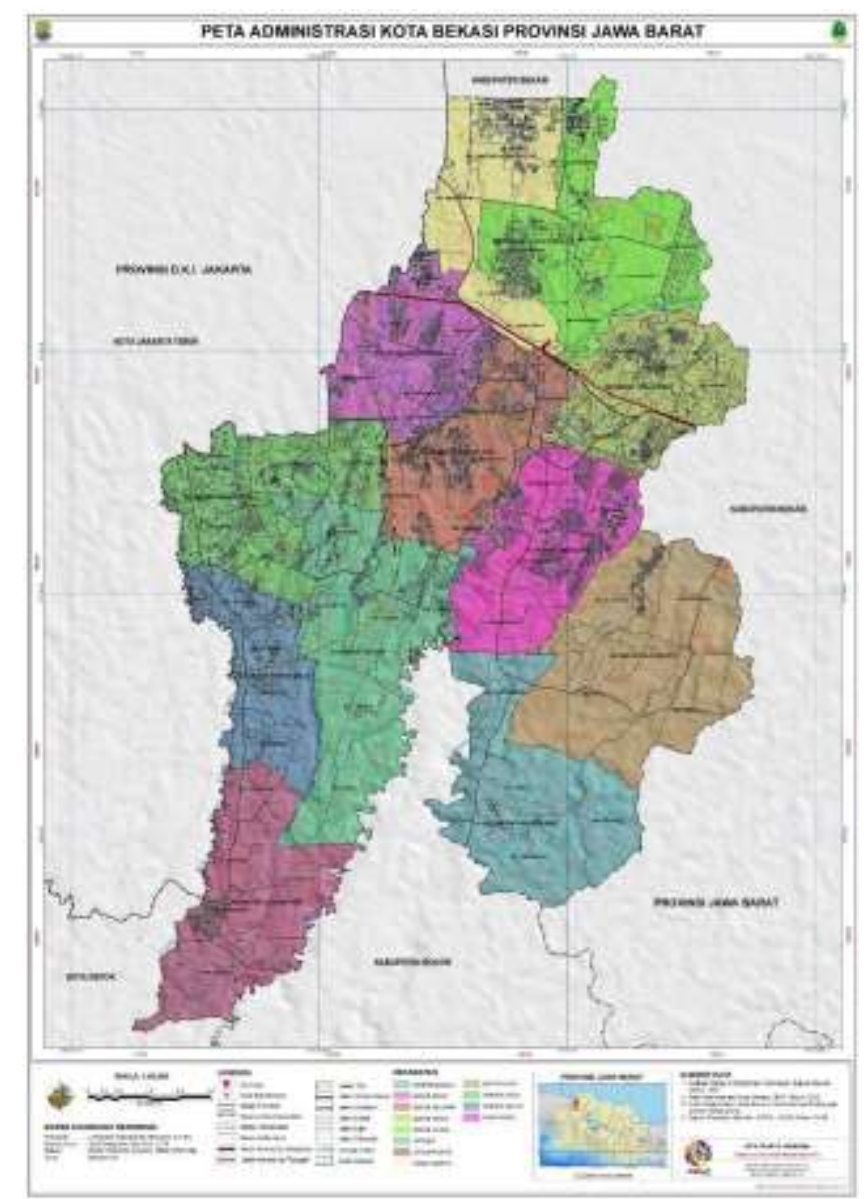

Gambar 1. Peta Administrasi Kota Bekasi 
Tabel 1.

Luas Daerah Menurut Kecamatan di Kota Bekasi Tahun 2010

Kecamatan

Ibukota Kecamatan

Luas Total Area

Persentase

Subdistrict

Capital of Subdistrict

$(\mathrm{km} / \mathrm{sq} \cdot \mathrm{km})$

terhadap LuasKota

Percentage to

Jumlah

Municipal Area

\begin{tabular}{ccccc}
\hline Pondokgede & Jatiwaringin & 16,29 & 7,74 & 5 \\
\hline Jatisampurna & Jatisampurna & 14,49 & 6,88 & 5 \\
\hline Pondokmelati & Jatirahayu & 18,57 & 8,82 & 4 \\
\hline Jatiasih & Jatiasih & 22,00 & 10,45 & 6 \\
\hline Bantargebang & Bantargebang & 17,04 & 8,10 & 4 \\
\hline Mustikajaya & Mustika Jaya & 24,73 & 11,75 & 4 \\
\hline Bekasi Timur & Bekasi Jaya & 13,49 & 6,41 & 4 \\
\hline Rawalumbu & Bojong Rawalumbu & 15,67 & 7,44 & 4 \\
\hline Bekasi Selatan & Pekayon Jaya & 14,96 & 7,11 & 5 \\
\hline Bekasi Barat & Bintara & 18,89 & 8,97 & 5 \\
\hline Medan Satria & Medan Satria & 14,71 & 6,99 & 4 \\
\hline Bekasi Utara & Perwira & 19,65 & 9,33 & 6 \\
\hline Bekasi Municipality & Marga Jaya & 210,49 & 100 & 56 \\
\hline
\end{tabular}

Tabel 2.

Luas Daerah Menurut Kecamatan di Kota Bekasi Tahun 2019

\begin{tabular}{|c|c|c|c|c|}
\hline $\begin{array}{l}\text { Kecamatan } \\
\text { Subdistrict }\end{array}$ & $\begin{array}{c}\text { Ibukota Kecamatan } \\
\text { Capital of Subdistrict }\end{array}$ & $\begin{array}{l}\text { Luas Total Area } \\
\quad(\mathrm{km} / \mathrm{sq} \cdot \mathrm{km})\end{array}$ & $\begin{array}{l}\text { Persentase terhadap LuasKota } \\
\text { Percentage to Municipal Area }\end{array}$ & $\begin{array}{l}\text { Jumlah } \\
\text { Kelurahan }\end{array}$ \\
\hline Pondokgede & Jatiwaringin & 15,92 & 7,56 & 5 \\
\hline Jatisampurna & Jatisampurna & 19,54 & 9,28 & 5 \\
\hline Pondokmelati & Jatirahayu & 11,80 & 5,61 & 4 \\
\hline Jatiasih & Jatiasih & 24,27 & 11,53 & 6 \\
\hline Bantargebang & Bantargebang & 18,44 & 8,76 & 4 \\
\hline Mustikajaya & Mustika Jaya & 26,42 & 12,55 & 4 \\
\hline Bekasi Timur & Bekasi Jaya & 14,63 & 6,95 & 4 \\
\hline Rawalumbu & Bojong Rawalumbu & 16,85 & 8,01 & 4 \\
\hline Bekasi Selatan & Pekayon Jaya & 16,06 & 7,63 & 5 \\
\hline Bekasi Barat & Bintara & 14,93 & 7,09 & 5 \\
\hline Medan Satria & Medan Satria & 11,88 & 5,65 & 4 \\
\hline Bekasi Utara & Perwira & 19,75 & 9,38 & 6 \\
\hline Bekasi Municipality & Marga Jaya & 210,49 & 100 & 56 \\
\hline
\end{tabular}

Tabel 3.

Kepadatan Penduduk Kota Bekasi Tahun 2010 dan Tahun 2019

\begin{tabular}{lcc}
\hline \multicolumn{1}{c}{$\begin{array}{c}\text { Kecamatan } \\
\text { Districts }\end{array}$} & $\begin{array}{c}\text { KepadatanPenduduk Population } \\
\text { Density } \\
\left(\text { jiwa / km }{ }^{2} \text { )Tahun 2010 }\right.\end{array}$ & $\begin{array}{c}\text { KepadatanPenduduk PopulationDensity } \\
\left(\text { jiwa / km }{ }^{2} \text { Tahun 2019 }\right.\end{array}$ \\
\hline Pondok gede & 14.462 & 14.342 \\
Jati Sampurna & 5.389 & 5.435 \\
Pondok Melati & 6.267 & 10.780 \\
Jati Asih & 8.396 & 9.299 \\
Bantar Gebang & 5.179 & 5.714 \\
Mustika Jaya & 5.279 & 7.386 \\
Bekasi Timur & 16.449 & 18.552 \\
Rawa Lumbu & 10.817 & 13.091 \\
Bekasi Selatan & 12.839 & 13.165 \\
Bekasi Barat & 12.813 & 18.074 \\
Medan Satria & 9.528 & 13.272 \\
Bekasi Utara & 14.481 & 16.706 \\
Bekasi Municipality & 9.903 & 11.634 \\
\hline
\end{tabular}


Tabel 4.

Perbandingan Per Kecamatan Penggunaan Lahan Kota Bekasi Tahun 2010 danTahun 2019

\begin{tabular}{lcccccccc}
\hline $\begin{array}{c}\text { Kecamatan } \\
\text { Districts }\end{array}$ & $\begin{array}{c}\text { Luas Kawasan } \\
\text { Terbangun }\end{array}$ & \multicolumn{2}{c}{$\begin{array}{c}\text { Luas Ruang } \\
\text { Terbuka Hijau }\end{array}$} & \multicolumn{2}{c}{$\begin{array}{c}\text { \% Luas } \\
\text { Kawasan } \\
\text { Terbangun }\end{array}$} & $\begin{array}{c}\text { \% Luas Ruang } \\
\text { Terbuka Hijau }\end{array}$ \\
\cline { 2 - 10 } & 2010 & 2019 & 2010 & 2019 & 2010 & 2019 & 2010 & 2019 \\
\hline Pondok gede & 1151 & 1165 & 280 & 276 & 7,72 & 7,69 & 6,43 & 6,34 \\
\hline Jati Sampurna & 1581 & 1577 & 255 & 255 & 10,60 & 10,41 & 5,86 & 5,86 \\
\hline Pondok Melati & 916 & 916 & 243 & 243 & 6,14 & 6,04 & 5,58 & 5,59 \\
\hline Jati Asih & 1653 & 1653 & 817 & 817 & 11,08 & 10,91 & 18,76 & 18,78 \\
\hline Bantar Gebang & 1341 & 1341 & 379 & 379 & 8,99 & 8,85 & 8,70 & 8,71 \\
\hline Mustika Jaya & 2001 & 2016 & 290 & 290 & 13,42 & 13,30 & 6,66 & 6,67 \\
\hline Bekasi Timur & 975 & 975 & 248 & 248 & 6,54 & 6,43 & 5,70 & 5,70 \\
\hline Rawa Lumbu & 1122 & 1135 & 422 & 422 & 7,52 & 7,49 & 9,69 & 9,70 \\
\hline Bekasi Selatan & 1026 & 1026 & 471 & 471 & 6,88 & 6,77 & 10,82 & 10,83 \\
\hline Bekasi Barat & 915 & 930 & 388 & 388 & 6,13 & 6,14 & 8,91 & 8,92 \\
\hline Medan Satria & 871 & 930 & 224 & 224 & 5,84 & 6,14 & 5,14 & 5,15 \\
\hline Bekasi Utara & 1363 & 1456 & 337 & 337 & 9,14 & 9,61 & 7,74 & 7,75 \\
\hline Bekasi Municipality & 14.915 & 15.155 & 4354 & 4350 & 100 & 100 & 100 & 100 \\
\hline
\end{tabular}

Panjang jalan suatu daerah juga sangat menentukan perkembangan masyarakat pada daerah tersebut, karena semakin banyak akses ke luar wilayah maka semakin tinggi tingkat perkembangan daerah tersebut. Pada tahun 2010, Kota Bekasi memiliki panjang jalan mencapai $1.315 .20 \mathrm{~km}$ dengan rincian $81.50 \mathrm{~km}$ jalan primer, $292.70 \mathrm{~km}$ jalan sekunder. Hingga tahun 2019, Kota Bekasi memiliki panjang jalan mencapai 4.548,58 km. Seiring bertambahnya tahun, maka luas daerah pada suatu kota juga mengalami perkembangan. Sejak tahun 2010 hingga 2019, beberapa kecamatan di Kota Bekasi mengalami perkembangan luas wilayah yang berbeda-beda.

\section{Persentase Luas Wilayah Menurut Kecamatan Tahun 2010}

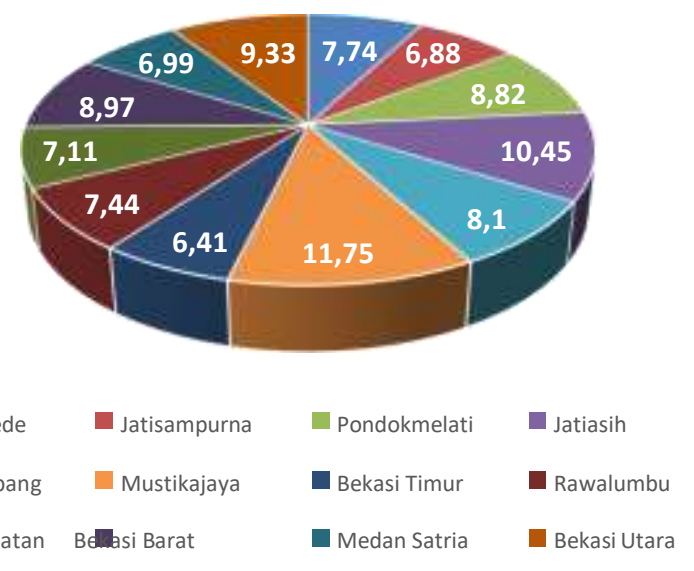




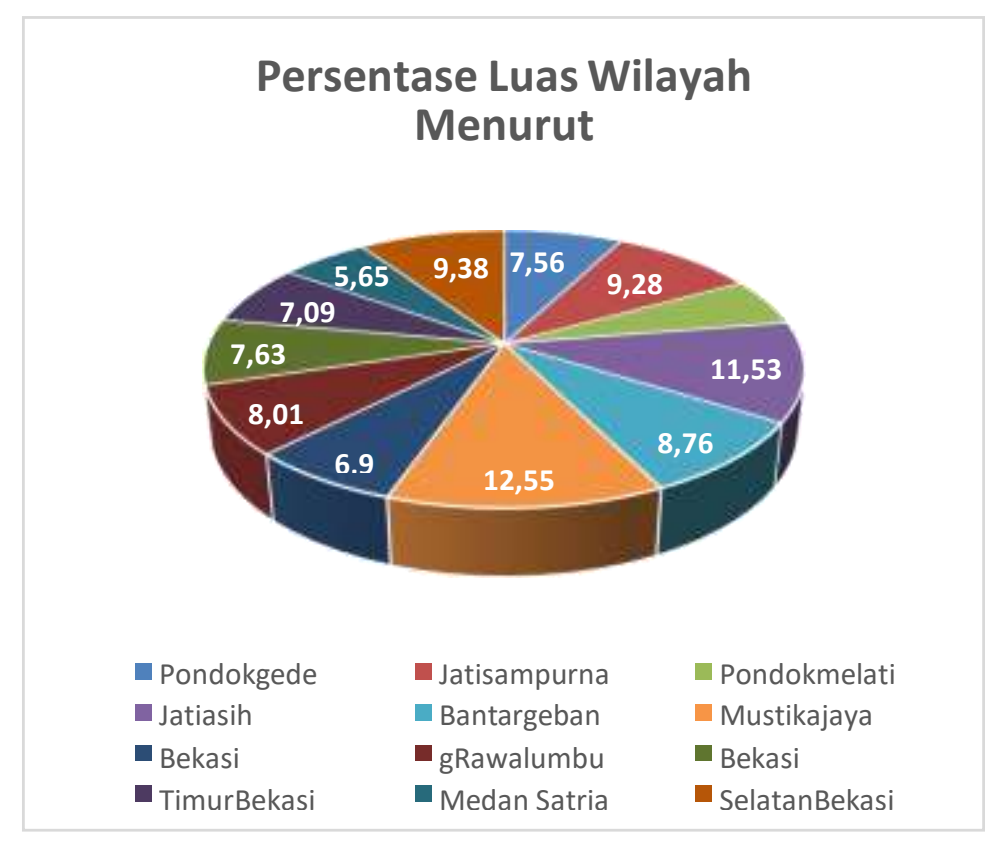

Selain perkembangan luas wilayah, jumlah penduduk dan kepadatan juga semakin bertambah. Menurut Kota Bekasi Dalam Angka Tahun 2010 dan 2019 diketahui bahwa kepadatan penduduk pada Tahun 2010 yaitu 9.903 jiwa $/ \mathrm{km}^{2}$ dan Tahun 2019 yaitu 11.634 jiwa $/ \mathrm{km}^{2}$.

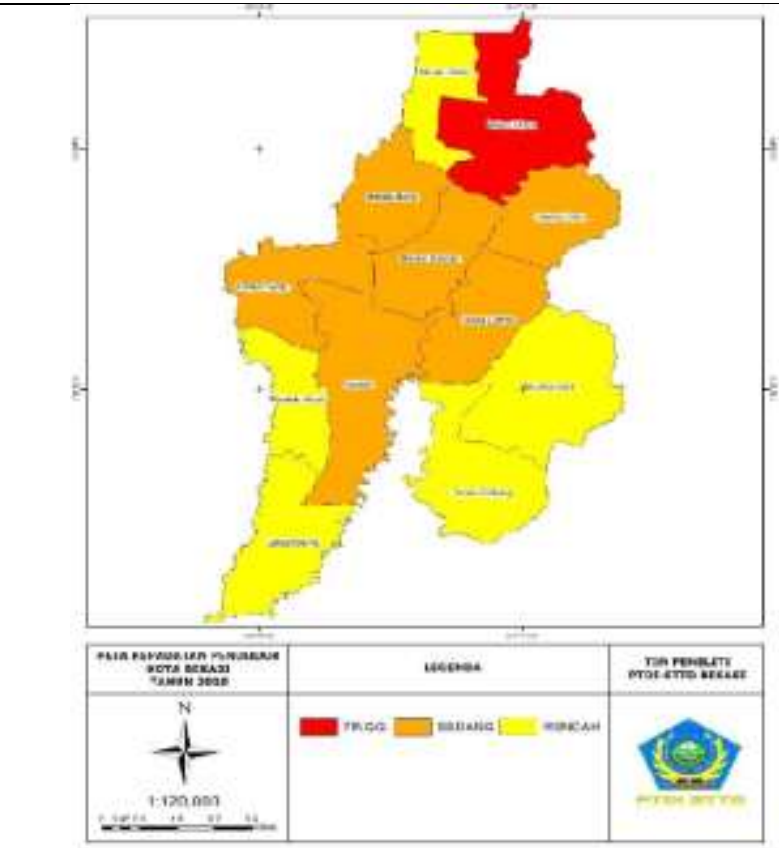

Gambar 2. Peta Kepadatan PendudukKota Bekasi Tahun 2010

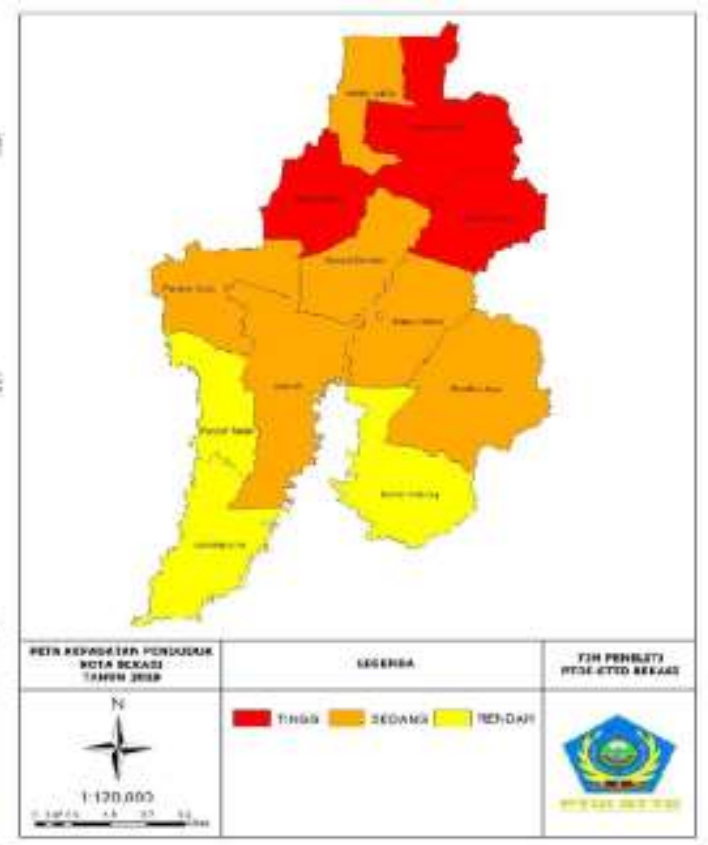

Gambar 3. Peta Kepadatan Penduduk Kota Bekasi Tahun 2019

Peta tersebut menunjukkan bahwa terdapat beberapa kecamatan yang mengalami peningkatan jumlah penduduk, misalnya yaitu Medan Satria dan Mustika Jaya yang awalnya menunjukkan warna kuning (rendah) pada tahun 2010 lalu menjadi warna orange (sedang). Selain itu, Kecamatan Bekasi Timur dan Bekasi Barat juga mengalami peningkatan yaitu dari warna orange (sedang) menjadi warna merah (tinggi). Ketersediaan Ruang Terbuka Hijau di Kota Bekasi Tahun 2019 semakin berkurang dikarenakan adanya peningkatan jumlah penduduk 
yang mana hal tersebut akan menambah persentase lahan/kawasan terbangun. Persentase Lahan Terbangun meningkat sebesar $1,02 \%$. Hal yang mengalami perubahan akibat adanya perkembangan wilayah dan kepadatan salah satunya yaitu perubahan fungsi tata guna lahan. Menurut data Rencana Pembangunan Jangka Menengah Daerah Kota Bekasi Tahun 20182023, penggunaan lahan terbesar pertama yaitu untuk pemukiman, lalu yang kedua yaitu lahan industri.

Tabel 5.

Perubahan Tata Guna Lahan Kota Bekasi dari Tahun 2010 ke Tahun 2019

\begin{tabular}{lcc}
\hline \multicolumn{1}{c}{ Kecamatan Districts } & \multicolumn{2}{c}{ Tata Guna Lahan (Land Use) } \\
\cline { 2 - 3 } & 2010 & 2019 \\
\hline Pondok gede & Pemukiman & Pemukiman \\
\hline Jati Sampurna & Pemukiman & Pemukiman \\
\hline Pondok Melati & Pemukiman & Pemukiman \\
\hline Jati Asih & Perkebunan & Industri dan TPA \\
\hline Bantar Gebang & Industri dan TPA & Pendidikan \\
\hline Mustika Jaya & Pemukiman & Pendidikan \\
\hline Bekasi Timur & Pemukiman & Pemukiman \\
\hline Rawa Lumbu & Pemukiman & Pusat Perbelanjaan \\
\hline Bekasi Selatan & Pemukiman & Kantor Pemerintahan \\
\hline Bekasi Barat & Pemukiman & Industri \\
\hline Medan Satria & Industri & Pusat Perbelanjaan \\
\hline Bekasi Utara & Pemukiman & \\
\hline
\end{tabular}

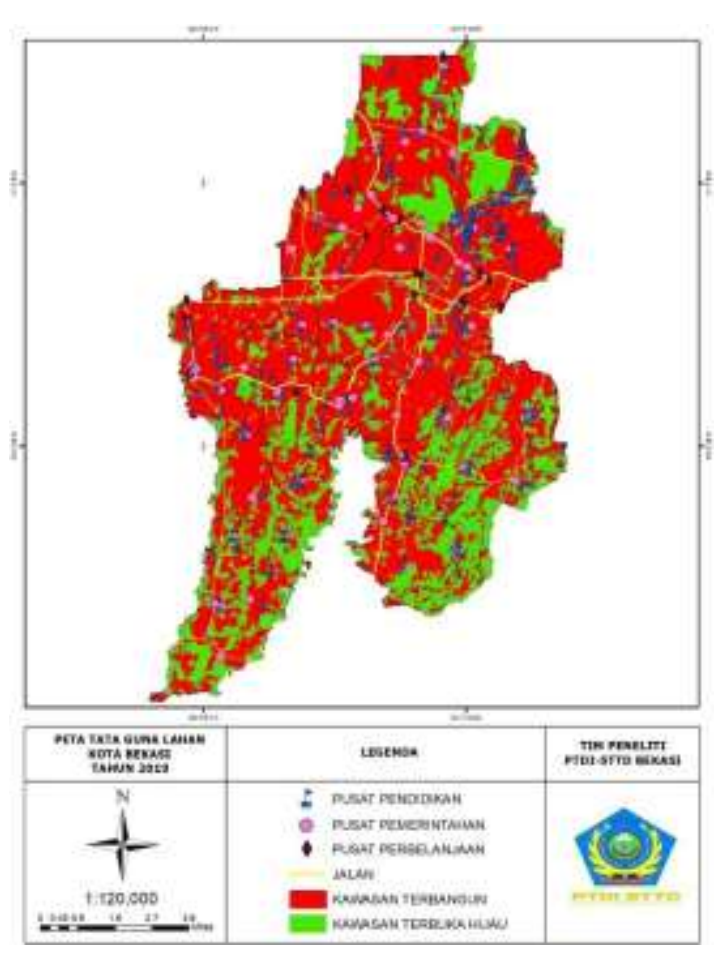

Gambar 4. Peta Tata Guna Lahan Kota BekasiTahun 2010

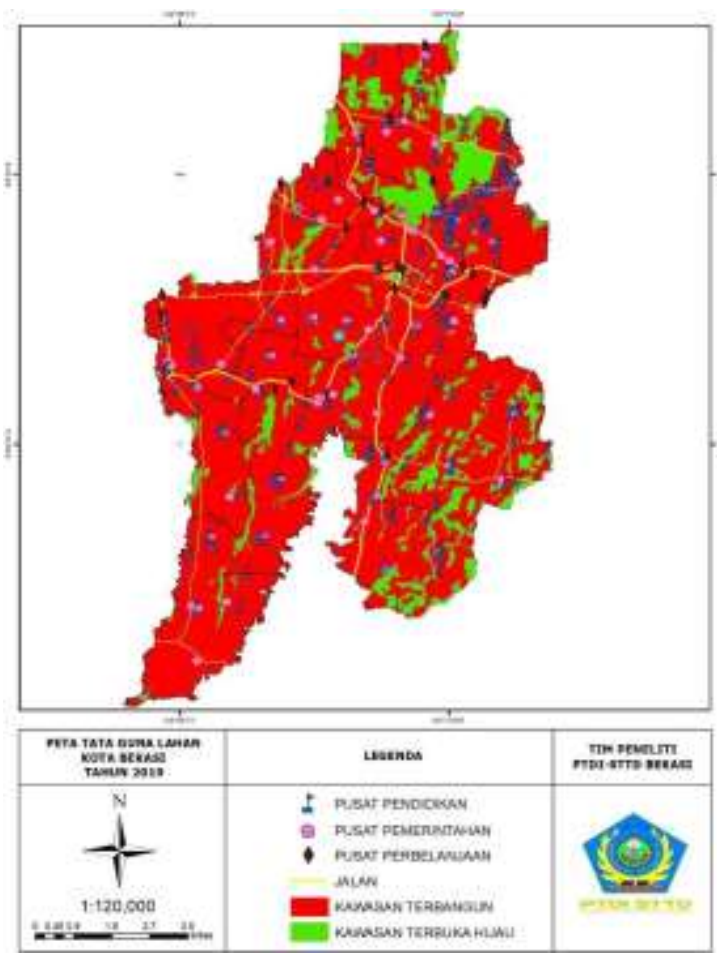

Gambar 5. Peta Tata Guna Lahan Kota BekasiTahun 2019 
Pola Implikasi Spasial Transportasi dengan Tata Guna Lahan Penggunaan Lahan Kota Bekasi Untuk menentukan teknis klasifikasi pada wilayah studi pada penelitian ini adalah klasifikasi secara digital pada data yang sudah melalui koreksi geometrik dengan metode klasifikasi supervised menggunakan algoritma maximum likelihood classification. Kemudian untuk melihat hubungannya dengan kepadatan wilayah penelitian inimenggunakan rumus:

\section{$(\mathrm{X} / \mathrm{Y}) \times 100 \%$}

Keterangan:

$\mathrm{X}=$ Luas bangunan yang didapat

$\mathrm{Y}=$ Luas daerah

Tabel 6.

Analisis Supervised Tata Guna Lahan Kota Bekasi

\begin{tabular}{lccc}
\hline Kecamatan Subdistrict & Luas Bangunan & Luas Daerah & $\begin{array}{c}\text { Hasil Supervised (luas } \\
\text { bangunan/luasdaerah)x } 100 \%\end{array}$ \\
\hline Pondokgede & 11,65 & 15,92 & $73,17 \%$ \\
\hline Jatisampurna & 15,77 & 19,54 & $80,70 \%$ \\
\hline Pondokmelati & 9,16 & 11,80 & $77,62 \%$ \\
\hline Jatiasih & 16,53 & 24,27 & $68,10 \%$ \\
\hline Bantargebang & 13,41 & 18,44 & $72,72 \%$ \\
\hline Mustikajaya & 20,16 & 26,42 & $76,30 \%$ \\
\hline Bekasi Timur & 9,75 & 14,63 & $66,64 \%$ \\
\hline Rawalumbu & 11,35 & 16,85 & $67,35 \%$ \\
\hline Bekasi Selatan & 10,26 & 16,06 & $63,88 \%$ \\
\hline Bekasi Barat & 9,30 & 14,93 & $62,41 \%$ \\
\hline Medan Satria & 9,30 & 11,88 & $78,28 \%$ \\
\hline Bekasi Utara & 14,56 & 19,75 & $73,72 \%$ \\
\hline
\end{tabular}

Analisis perubahan luas kawasan terbangun menunjukkan pada umumnya seluruh wilayah kecamatan di Kota Bekasi mengalami perubahan yang signifikan. Wilayah-wilayah seperti Jatisampurna dan Medan Satria memiliki tingkat kepadatan kawasan terbangun yang tinggi mengalami perluasan yang bervariasi yaitu lebih dari $70 \%$ dari total luas wilayah.

Desire line

Sebelum dilakukan analisis distribusi perjalanan, ditentukan pembagian zona menurut kecamatan yang ada di Kota Bekasi. Berikut Zona Perjalanan Kota Bekasi:

Tabel 7.

Zona Perjalanan Kota Bekasi

\begin{tabular}{|c|c|}
\hline Zona & Kecamatan \\
\hline 1 & Medan Satria \\
\hline 2 & Bekasi Utara \\
\hline 3 & Bekasi Barat \\
\hline 4 & Bekasi Timur \\
\hline 5 & Bekasi Selatan \\
\hline 6 & Rawa Lumbu \\
\hline 7 & Mustika Jaya \\
\hline 8 & Jatiasih \\
\hline 9 & Pondok Gede \\
\hline 10 & Pondok Melati \\
\hline 11 & Jatisampurna \\
\hline 12 & Bantar Gebang \\
\hline
\end{tabular}




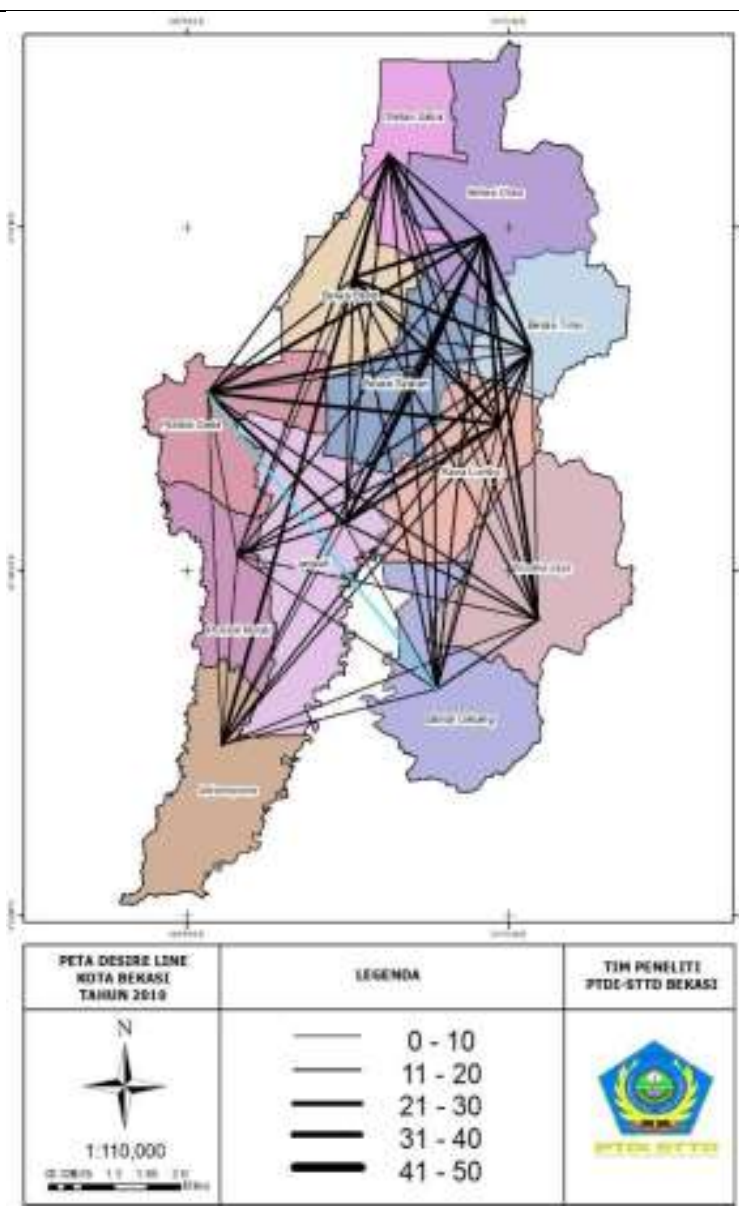

Gambar 5. Peta Desire Line KotaBekasi

Tahun 2010

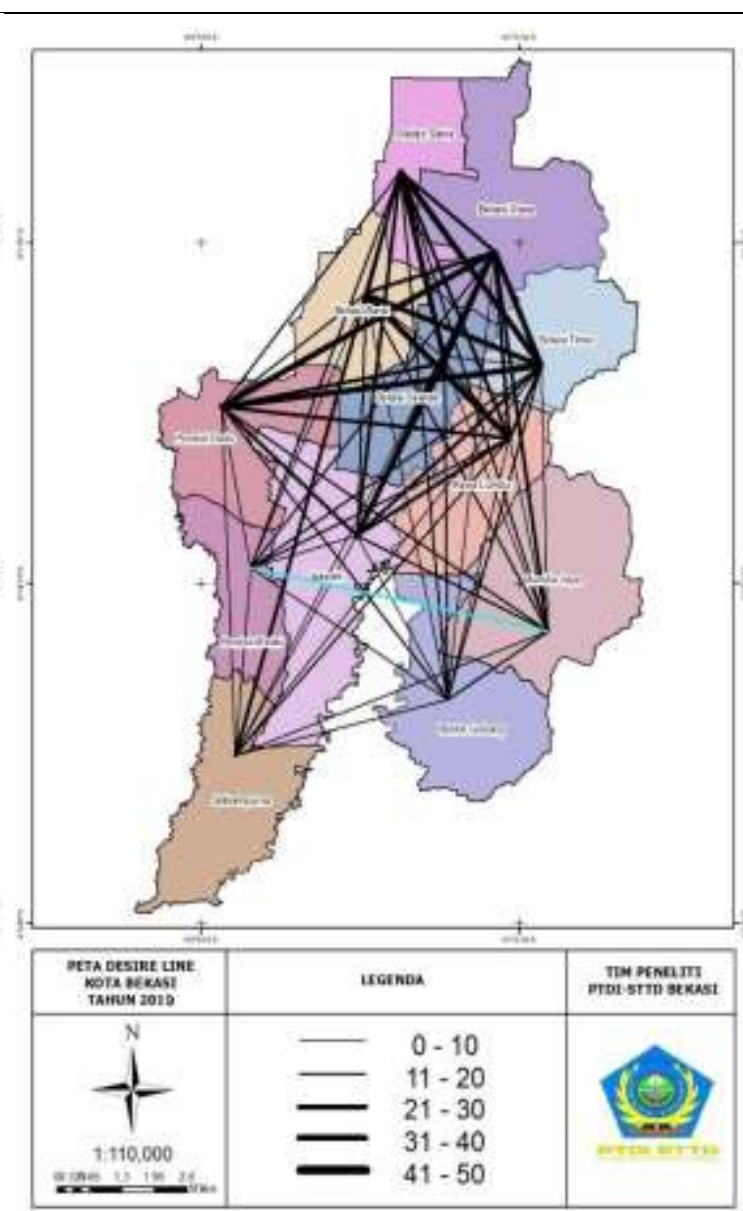

Gambar 6. Peta Desire Line KotaBekasi

Tahun 2019

Menurut Peta Desire Line Kota Bekasi diatas, dapat dilihat bahwa Zona 2 yaitu Kecamatan Bekasi Utara memiliki bangkitan dan tarikan yang tertinggi baik pada Tahun 2010 dan Tahun 2019. Sementara untuk bangkitan dan tarikan yang terendah Tahun 2010 yaitu pada Kecamatan Jatisampurna dan Tahun 2019 yaitu kecamatan Bantar Gebang. Titik centroid pada tahun 2010 yaitu pada Kecamatan Bekasi Utara, Bekasi Barat, dan Pondok gede. Sedangkan pada tahun 2019 terjadi perubahan salah satu titik centroid pada Kecamatan Pondok Gede menjadi Kecamatan Bekasi Timur.

\section{SIMPULAN}

Pola perkembangan kawasan terbangun Kota Bekasi berdasarkan analisis yang menunjukkan bahwa setiap kecamatan di Kota Bekasi mengalami pertambahan luasan kawasan terbangun yang cukup siginifikan. Jumlah persentase kawasan terbangun dari 2010-2019 meningkat sebesar $1,02 \%$. Peningkatan persentase kawasan terbangun dipengaruhi juga oleh laju pertumbuhan penduduk yang menyebabkan meningkatnya kepadatan penduduk. misalnya yaitu kepadatanpenduduk Kecamatan Medan Satria Tahun 2010 yaitu $9.528 \mathrm{jiwa} / \mathrm{km}^{2}$ menjadi 13.272 jiwa $/ \mathrm{km}^{2}$ pada Tahun 2019. Perubahan fungsi tata guna lahan di beberapa daerah dapat mempengaruhi kegiatan transportasi sehingga menyebabkan peningkatan jumlah perjalanan dari satu daerah ke daerah lain. Sebagai contoh Kecamatan Bekasi Utara dan Bekasi Selatan yang awalnya merupakan mayoritas adalah pemukiman saat ini berkembang menjadi pusat perbelanjaan, hal itu membuat perjalanan bertambah menuju ke daerah tersebut. Berdasarkan hasil analisis distribusi perjalanan bahwasanya terdapat ketimpangan spasial terkait 
perkembangan fungsi guna lahan yaitu pada Kecamatan Bekasi Utara dan Kecamatan Bantar Gebang. Dimana Kecamatan Bekasi Utara memiliki tingkat bangkitan dan tarikan tertinggi baik dari tahun 2010 dan 2019, sedangkan Kecamatan Bantar Gebang memiliki bangkitan dan tarikan terendah. Faktor utama penyebab pertumbuhan yang sangat pesat tersebut adalah Kota Bekasi yang terhubung atau berbatasan langsung dengan kota megapolitan DKI Jakarta dan Kabupaten Bekasi menjadi rencana pusat kegiatan nasional berupa kawasan industri.

\section{DAFTAR PUSTAKA}

Badan Perencanaan Pembangunan Daerah Kota Bekasi. Rencana Pembangunan Jangka Menengah Daerah Tahun 2018-2023. Kota Bekasi: Badan Perencanaan Pembangunan Daerah Kota Bekasi.

Badan Pusat Statistik Kota Bekasi. 2011. Kota Bekasi Dalam Angka 2011. Kota Bekasi: Badan Pusat Statistik Kota Bekasi.

Badan Pusat Statistik Kota Bekasi. 2020. Kota Bekasi Dalam Angka 2020. Kota Bekasi: Badan Pusat Statistik Kota Bekasi.

Cahyaningtyas, Yeda Nurul., Rahayu, Sri. 2014. Kajian Perkembangan Penggunaan Lahan dan Fungsi Bangunan Sekitar Pusat Perbelanjaan (Mal) di Kota Bekasi. Kota Semarang: Universitas Diponegoro.

Munibah $d k k$. 2010. Dampak Perubahan Penggunaan Lahan Terhadap Erosi di DAS Cidanau Banten. Bogor: Institut Pertanian Bogor.

Sitorus, Satun Risma Pandapotan., Leonataris, Citra., Panuju, Dyah Retno. 2012. Analisis Pola Perubahan dan Penggunaan Lahan Perkembangan Wilayah di Kota Bekasi Jawa Barat. Bogor: Institut Pertanian Bogor. 